$\xi=$

\title{
Investigation of Ground Water Depletion Pattern across Chennai City
}

\author{
Soundarya.M.K ${ }^{1 *}$, Thanga Gurusamy. $\mathbf{B}^{2}$ \\ ${ }^{1}$ Assistant Professor, Department of Civil Engineering, Vels Institute of Science, Technology and Advanced Research Studies, Chennai. \\ ${ }^{2}$ Assistant Professor, Department of Civil Engineering, Vels Institute of Science, Technology and Advanced Research Studies, Chennai. \\ *Corresponding author E-mail: mk.soundaryaa@gmail.com
}

\begin{abstract}
An attempt has been made to investigate both seasonal and long term ground water depletion pattern across the aquifers lying below geographical boundary of Chennai city. The Depth below Ground Level (DBGL) is used as an analyzing parameter for this investigation. This analysis is based on the data that has been made available to the public by Central Ground Water Board (CGWB) and Water Resources Department, Chennai, Tamil Nadu. Both graphical analysis and statistical based regression analysis has been carried out and the result has been presented in graphical and tabular form. Seasonal DBGL variation has been analyzed for the year 2016 after the popular Chennai 2015 December Flood event. It has been observed that the range of ground water level depletion is from $0.1 \mathrm{~m}$ per month at Broadway and up to $0.833 \mathrm{~m}$ per month at T.S.Campus locations during post monsoon season from January to May. Long term DBGL variation has been analyzed for duration of 22 years from 1996 to 2017. Statistical package for social sciences (SPSS) has been used to perform both linear and other regression analysis. Sustained decrease in ground water level has been observed at locations like Perambur Kodambakkam and Vallalar Nagar during the last two decades.
\end{abstract}

Keywords: Conjunctive water use;Depth below ground level (DBGL); Ground water depletion; Regression coefficient

\section{Introduction}

It has been estimated by UNESCO, 1975 that the total quantity of water in the world is to be about 1386 million cubic kilometer (M $\mathrm{km}^{3}$ ). About $96.5 \%$ of this water is contained in the ocean as saline water. Only $35 \mathrm{M} \mathrm{km}^{3}$ of fresh water is available because about $1 \%$ of water available in the land is also saline. Out of this $24.4 \mathrm{M} \mathrm{km}^{3}$ of water is contained in frozen state as ice in the polar region. The remaining $10.6 \mathrm{M} \mathrm{km}^{3}$ is both liquid and fresh.

The hydrological phenomena changes the contribution of ground water potential with respect to that of other sources of water. With respect to Surface water the ground is a kind of sustained water that is available for a long period of time after the given rain fall. The reliability of the ground water is much higher than that of surface water.

Hence for the efficient management of the ground water potential the monitoring of the ground water depletion pattern and modeling of the ground water flow pattern becomes the area of focus.

\section{Literature Review}

The conjunctive use of surface and ground water strategy is always used to optimize the water resources management practices. Agricultural Statistics at Glance $2014^{[1]}$ reported that the increase in the use of ground water for irrigation is from $30 \%$ to $60 \%$ during the last six decades and there is corresponding decrease in the surface water usage as in figure 2.1. Water and related statistics, April $2015^{[2]}$ has reported that out of the total annual water availability of 1,869 Billion Cubic Meter (BCM)/year, the usable water resources of the country have been estimated as $1,123 \mathrm{BCM} / \mathrm{year}$. This is due to constraints of topography and uneven distribution of the resource in various river basins, which makes it difficult to extract the entire available $1,869 \mathrm{BCM} /$ year. This 1,123 $\mathrm{BCM} / \mathrm{year}$ includes the ground water contribution of 433 $\mathrm{BCM} /$ year.

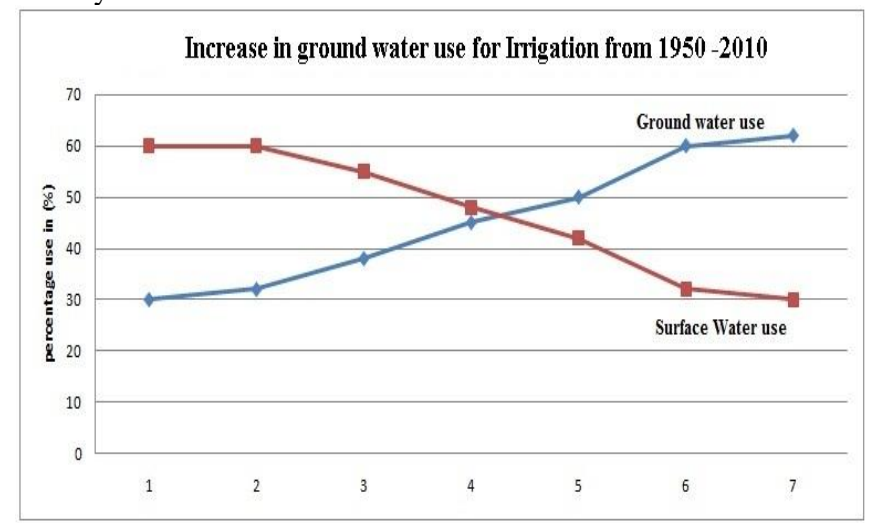

Fig.1 : Increase in ground water use for Irrigation 1940 to $2010^{[1]}$

Ground Water Yearbook, India 2013-14, July $2014^{[3]}$ has reported that the overall contribution of rainfall to the country's annual ground water resource is $68 \%$ and the share of other resources, such as canal seepage, return flow from irrigation, recharge from tanks, ponds and water conservation structures taken together is $32 \%$. Due to the increasing population and concentration of population measured in the form of population density rearranges the distribution of ground water potential and becomes the criteria for the efficient implementation of the conjunctive use of surface and ground water strategy. 


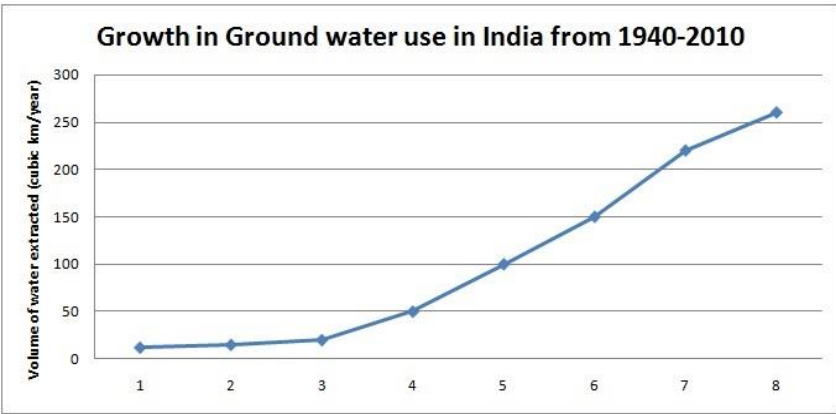

Fig.2 : Growth in ground water use in India From 1940 to $2010^{[4]}$

Barker, 2002 ${ }^{[4]}$ and Shah, 2009 ${ }^{[5]}$ reported that the increase in the ground water usage in India is much higher in the last six decades from $25 \mathrm{~km}^{3} /$ year to $275 \mathrm{~km}^{3} /$ year and this value is less than 100 $\mathrm{km}^{3} /$ year in all other countries as in figure 2.2. Shah, $2002^{[6]}$, presented that the watershed management approach and externalities that lead to groundwater depletion. Hazell and Fan 2001 ${ }^{[7]}$ has reported the Agricultural intensification and localized economic development for increased productivity has influenced the ground water depletion pattern. Rosegrant $2002^{[8]}$ presented that Irrigation accounts for over $90 \%$ of water consumption in India, as in many South Asian countries. Church $2007^{[9]}$ presented that At a World Climate Research Programme workshop held in 2006, participants highlighted the need for data on changes in subsurface water storage resulting from groundwater use changes and aquifer mining, among other factors.

Hira $2004^{[10]}$ presented that a major concern of the state is the rapid decline of water-table. About 77 per cent area of the state is facing the problem of falling water table. Marufur Rahman, 2012 [11] Successive depletion of groundwater level with expansion of groundwater irrigation has been discussed from mid 1960s to 2010 in the context of Tanore Upazila. Qureshi $2004^{[12]}$ presented the importance of conjunctive use to reduce the Ground water depletion.

\section{Study Area}

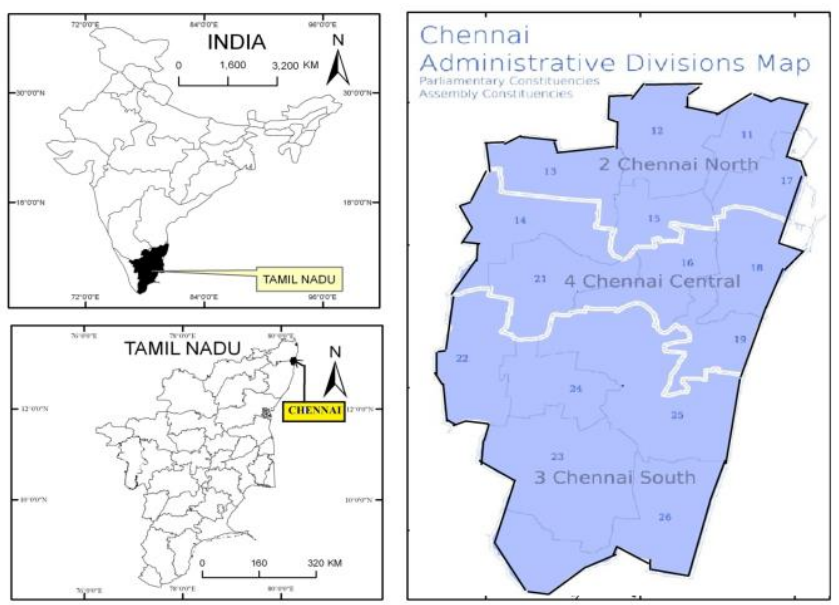

Fig.3: Location map of Chennai city.

Chennai city covers 176 sq.km having terrain slope 1: 5000 to 1: 10000.The Chennai city is in between the latitudes from $12.95^{\circ}$ to $13.15^{\circ}$ and longitudes $80.18^{\circ}$ and $80.30^{\circ}$. The city is drained by Coovum river,ADYAR river and KOSASTHALAIYAR river in the north. Major Flood events in CHENNAI city experienced during 1943, 1976,1985,1996,2005 and 2015.

Chennai Metropolitan area (CMA) covers 1189 sq.km and having population more than 86 LAKHS. The CMA falls in the three districts of the Tamil Nadu i.e. Chennai District (area: 176sq.km) and parts of Thiruvallur district (area: 637 sq.km) and Kanchipu- ram district (arera:376 sq.km). Coovum river starts from Kesavaram anicut in Kesavaram village built across Kortalaiyar river.

\section{Research Methodology}

A set of observation wells has been maintained by CGWB and Tamil Nadu Water Resources department. Chennai city covers about more than 30 wells. Ground Water level data for all wells are being recorded by the government department at a frequency of one data per one well per one month. These Data are being available for authorized purchase by students and research scholars. The well location map for Chennai city is shown in figure 4 .

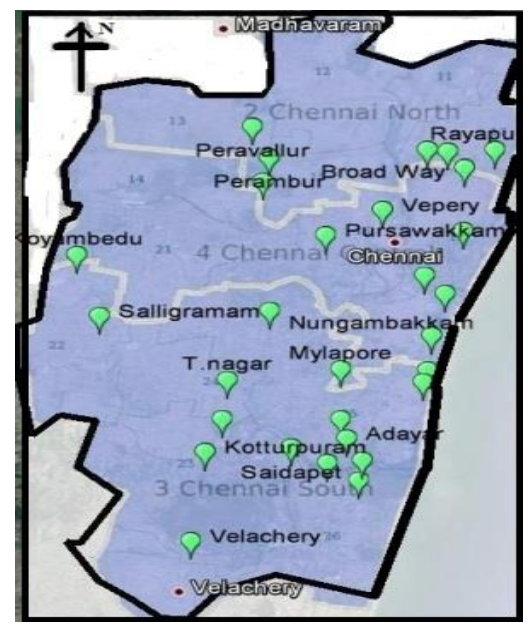

Fig.4: Location map of observation wells in Chennai

The ground water level data was received from Tamil Nadu Water Resources Department for Chennai city during the period of Jan 2016 to Dec 2016.The observed water level from measuring point is used to calculate Depth below Ground Level (DBGL),

DBGL = (Height of water level below measuring point - Height of measuring point above GL $)$

Absolute Ground water level $=($ Absolute Ground Level - DBGL $)$

Both graphical and Statistical methods were used to analyze the time varying ground water level data. A set of graphical plot were prepared individually for each wells and the graph was interpreted. Linear Regression modeling technique has been used to analyze the seasonal ground water depletion pattern for the year 2016 . Other curvilinear regression were used for the analysis of long term ground water depletion from 1996 to 2017 using the data provided by CGWB, Delhi.

Linear regression is a modeling in which the expected value of a dependent variable (here it is DBGL) is modeled as a linear combination of a set of explanatory variables. Since the trend of ground water level changes from the month of June as in figure 5 i.e. after the end of summer season, separate linear regression coefficients were determined for duration Jan-May and Jun-Dec and the results were shown in table 1

\section{JAN - DEC 2016 @ NUNGAMBAKKAM}

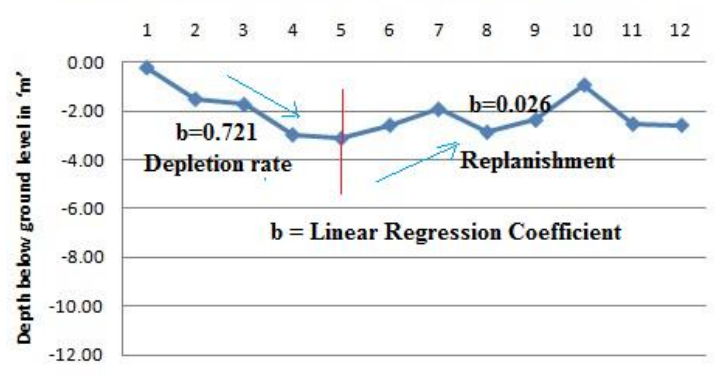

Fig.5: DBGL variations from Jan-Dec 2016 for Nungambakkam location 
With the simple Linear Regression model $\quad\left(\mathrm{y}_{\mathrm{i}}=\mathrm{a}+\mathrm{b}^{*} \mathrm{x}+\right.$ error $)$ the observed value of the dependent variable $y_{i}$ is composed of a linear function of $a+b^{*} x$ of the explanatory variable $\mathrm{x}$ together with the error. The sample output from Statistical package for social sciences (SPSS) is shown in figure 6 for Nungambakkam well location.

Model Summary and Parameter Estimates

Dependent Variable:VAR00002

\begin{tabular}{|c|c|c|c|c|c|c|c|}
\hline \multirow[b]{2}{*}{ Equation } & \multicolumn{5}{|c|}{ Model Summary } & \multicolumn{2}{|c|}{ Parameter Estimates } \\
\hline & R Square & $\mathrm{F}$ & df1 & $d f 2$ & Sig. & Constant & b1 \\
\hline Linear & .935 & 43.456 & 1 & 3 & .007 & 235 & -.721 \\
\hline
\end{tabular}

Fig.6: Sample SPSS output for Nungambakkam well location

\section{Results and Discussion}

The time varying DBGL plots are shown for selected well locations as shown in figure 7

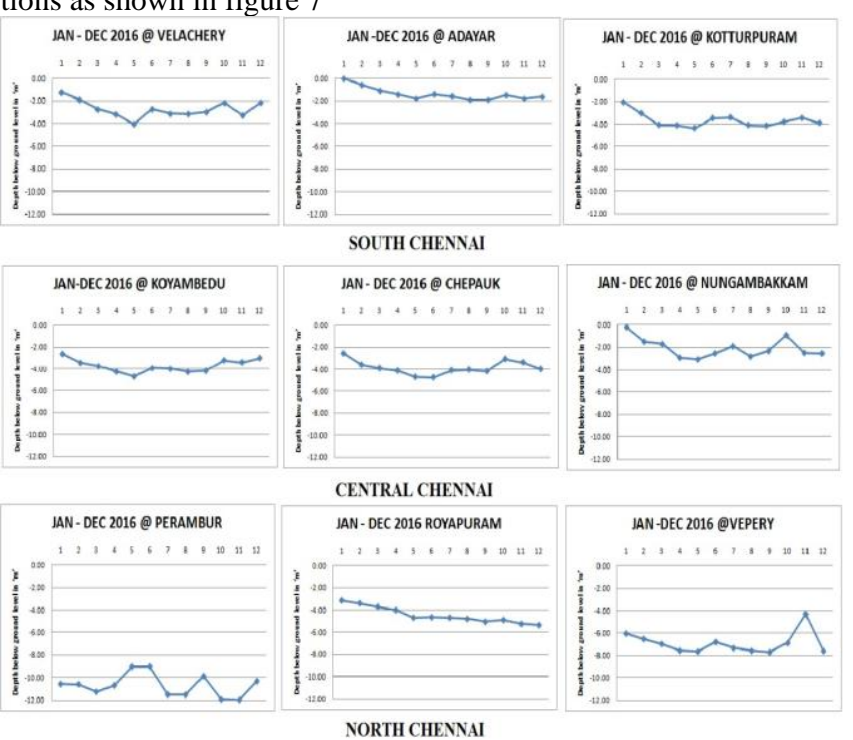

Fig.7: Time varying DBGL plot for selected wells from north, central and south Chennai

It is observed that during the period January to May there is lowering of ground water level. But after the end of summer season i.e. from the month of June the water level gets replenished. The separate regression coefficient for ground water depletion and then the correcting replenishment has been shown in the following table 1 . It has been observed that the range of ground water level depletion is from $0.1 \mathrm{~m}$ per month at Broadway and up to $0.833 \mathrm{~m}$ per month at T.S.Campus locations during post monsoon season from January to May 2016.

Particularly the ground water level at Permabur location was observed consistently $10 \mathrm{~m}$ below ground level as shown in Figure 7. A typical comparison regression coefficient of selected wells from each of north, central and south Chennai are shown in figure 8 Similarly the figure 9 shows the seasonal DBGL variations of the selected well group from north, central and south Chennai regions. The Long term DBGL variation across Chennai for various locations is shown in the figure 10.The long term DBGL variation for locations such as Perambur and Vallalar Nagar are shown in figure 11.In both locations there is consistent decrease in ground water level up to a magnitude of about $4 \mathrm{~m}$ during the last one decade.
Table 1: Jan-Dec 2016 depletion and replenishment rate in unit ' $\mathrm{m} /$ month'

\begin{tabular}{|c|c|c|c|c|}
\hline $\begin{array}{l}\text { S. } \\
\text { No }\end{array}$ & WELL LOCATION & $\begin{array}{l}\text { 2016 JAN-MAY } \\
\text { GWL Depletion } \\
\text { rate }(\mathrm{m} / \\
\text { month) }\end{array}$ & \multicolumn{2}{|c|}{$\begin{array}{l}2016 \text { JUN-DEC GWL } \\
\text { Replenishment rate } \\
\text { (m / month) }\end{array}$} \\
\hline 1 & Velachery & 0.683 & 0.084 & Replenishment \\
\hline 2 & Adayar & 0.241 & 0.077 & Replenishment \\
\hline 3 & Adayar Sports Club & 0.166 & -0.017 & Depletion \\
\hline 4 & T.S.Campus & 0.833 (HIGH) & $-0.307(\mathrm{HIGH})$ & Depletion \\
\hline 5 & Saidapet & 0.573 & -0.04 & Depletion \\
\hline 6 & Kotturpuram & 0.255 & 0.061 & Replenishment \\
\hline 7 & Andra Hopital & 0.443 & -0.026 & Depletion \\
\hline 8 & Saidapet & 0.817 & -0.192 & Depletion \\
\hline 9 & Greenways Road & 0.342 & 0.067 & Replenishment \\
\hline 10 & T.Nagar & 0.681 & 0.209 & Replenishment \\
\hline 11 & Nochikuppam & 0.352 & $-0.003(\mathrm{LOW})$ & Depletion \\
\hline 12 & Mylapore & 0.274 & -0.012 & Depletion \\
\hline 13 & $\begin{array}{l}\text { Lady Welligton } \\
\text { School }\end{array}$ & 0.568 & 0.05 & Replenishment \\
\hline 14 & Salligramam & 0.338 & $-0.003(\mathrm{LOW})$ & Depletion \\
\hline 15 & Nungambakkam & 0.721 & 0.026 (LOW) & Replenishment \\
\hline 16 & Chepauk Pwd & 0.471 & 0.164 & Replenishment \\
\hline 17 & Govt. Estate & 0.497 & $\begin{array}{l}-0.109 \\
\end{array}$ & Depletion \\
\hline 18 & Koyambedu & 0.498 & 0.184 (HIGH) & Replenishment \\
\hline 19 & Pursawakkam & 0.249 & -0.246 & Depletion \\
\hline 20 & Secretariat & 0.487 & -0.054 & Depletion \\
\hline 21 & Vepery & 0.426 & 0.155 & Replenishment \\
\hline 22 & Broad Way & 0.093 (LOW) & -0.012 & Depletion \\
\hline 23 & Perambur & 0.3 & -0.19 & Depletion \\
\hline 24 & Mint-Stanley Medical & 0.319 & -0.173 & Depletion \\
\hline 25 & Rayapuram & 0.365 & -0.117 & Depletion \\
\hline 26 & Peravallur & 0.144 & -0.022 & Depletion \\
\hline
\end{tabular}

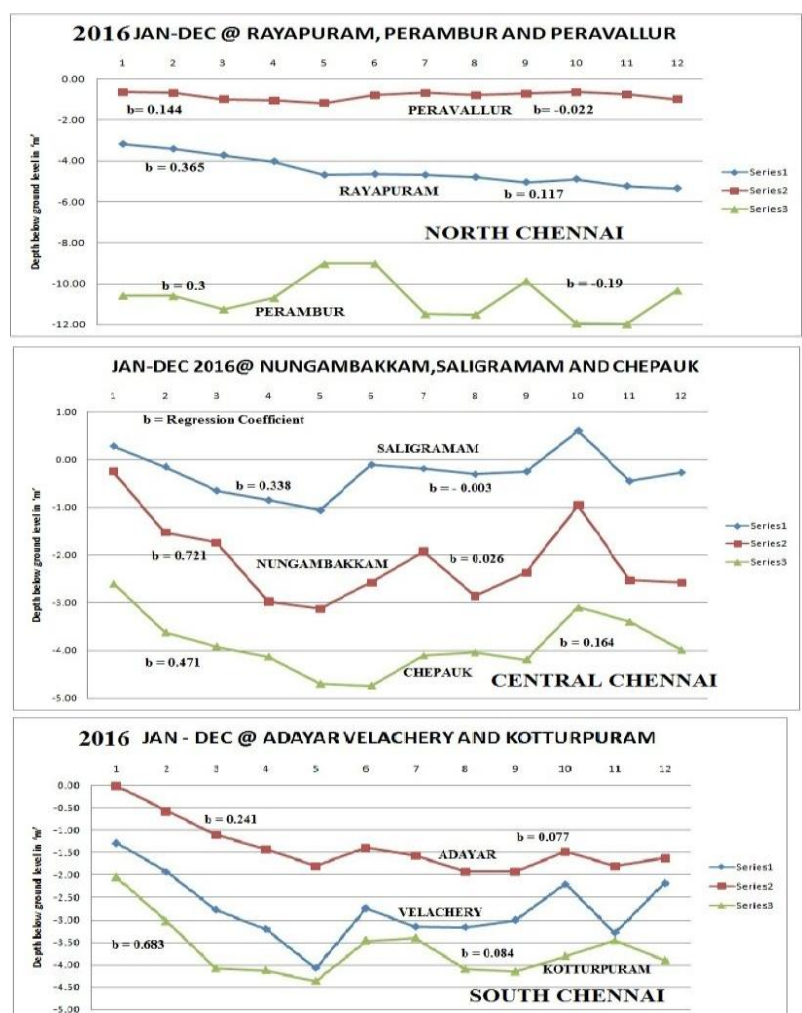

Fig. 8: Typical comparisons of seasonal regression coefficients of selected wells 


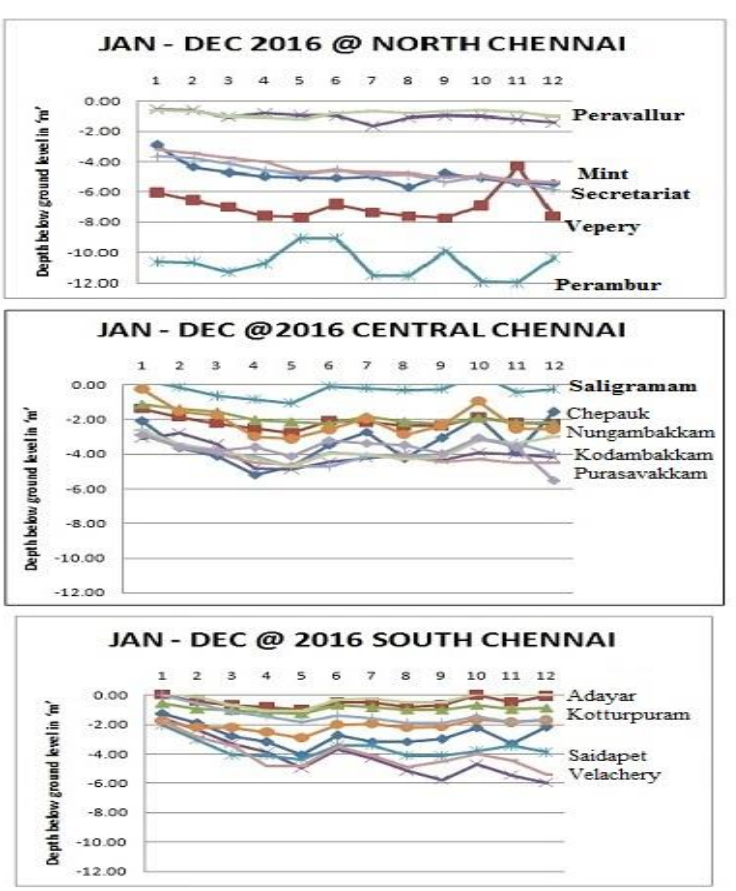

Fig.9: Typical comparisons of seasonal DBGL variation of selected wells

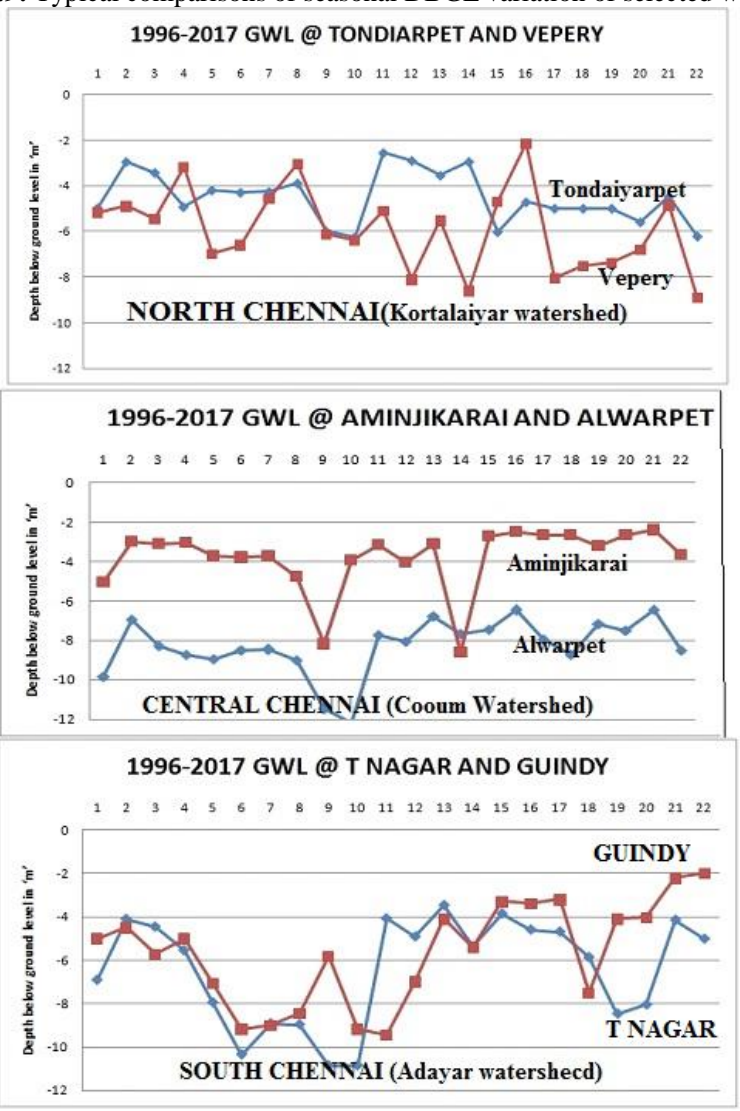

Fig.10: Long term DBGL variation across Chennai

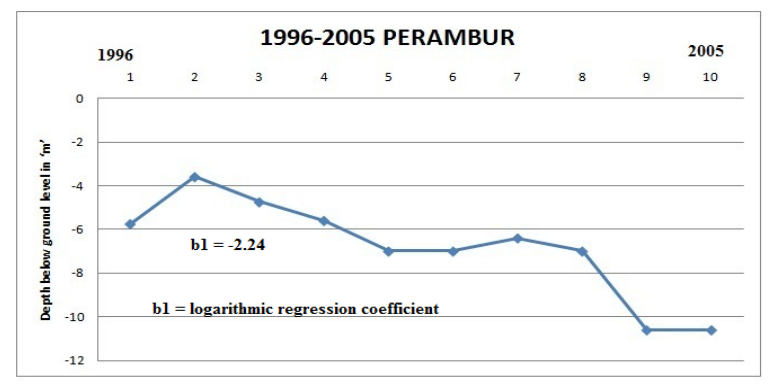

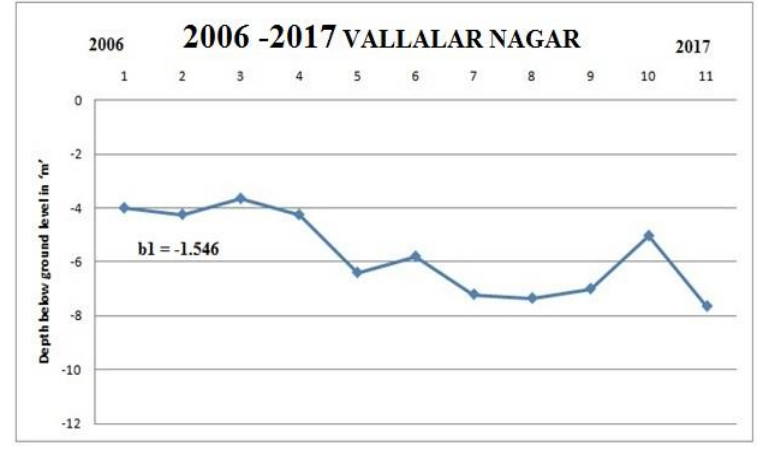

Fig.11: The long term DBGL variation for locations such as Perambur and Vallalar

\section{Conclusion}

Efficient water resources management practices may be ensured both by structural and non-structural measures. The conjunctive use of surface and ground water is one of the non-structural methods for the optimum usage existing ground water potential in collaboration with that of the surface water. Strategies for the management of conjunctive use of surface water and groundwater resources in semi-arid areas are presented by Quresh, 2004 ${ }^{[12]}$ in order to give an approach for optimizing the use of ground water potential and thereby to minimize the ground water depletion rate. Monitoring the ground water depletion rate will help us for efficient decision making during the water management practices. The modeling of ground water depletion rate as function of Characteristics of Aquifer, population intensity and agricultural productivity will be highly useful for controlling the depletion rate in order to ensure the optimum use of water resources potential in a local level as well as in global level.

\section{Acknowledgment}

The authors are highly grateful to the management of VELS Institute of Science, Technology and Advanced studies (VISTAS) for their consistent encouragement towards this research work and to the Executive Engineer, Tamil Nadu Water Resources Department Chennai, and CGWB, Delhi for their kind support to provide necessary ground water level data for the study area considered.

\section{Reference}

[1] Agricultural Statistics at Glance 2014, Ministry of Agriculture; India.

[2] Water and related statistics, April 2015, Central water commission, India.

[3] Ground Water Yearbook 2013-14, July 2014, Central Ground Water Board, India.

[4] Barker, R. and Molle, F. (2002) Perspectives on Asian irrigation. Paper presented at the Conference on Asian Irrigation in Transition - Responding to the Challenges Ahead, Asian Institute of Technology, Bangkok, Thailand, 22-23 April 2002.

[5] Shah, T.(2009) Taming of Anarchy: Ground water Governance in South Asia. RFF Press, Washington DC, USA.

[6] Shah T. 2002. The socio-ecology of groundwater in India. Water Policy Briefing, Issue No 4 International Water Management Institute, Colombo, Sri Lanka.

[7] Hazell P and Fan S. 2001. Balancing regional development priorities to achieve sustainable and equitable agricultural growth. In: Tradeoffs or synergies? Agricultural intensification, economic development and environment CABI Publishing. 151-170 pp.

[8] Rosegrant MW, Cai X and Cline S. 2002. World Water and Food to 2025: Dealing with Scarcity. International Food Policy Research Institute, Washington,DC

[9] Church, J., S. Wilson, P. Woodworth, and A. Thorkild (2007), Understanding sea level rise and vulnerability, Eos Trans. AGU, $88(4), 43$.

[10] Hira, G.S., Jalota, S.K. and Arora, V.K. (2004) Efficient Management of Water Resources for Sustainable Cropping in Punjab. 
Research Bulletin, Department of Soils, Punjab Agricultural University,Ludiana.

[11] Marufur Rahman Md, Mahbub A. Q. M. Groundwater Depletion with Expansion of Irrigation in Barind Tract: A Case Study of Tanore Upazila Journal of Water Resource and Protection, 2012, 4, 567-575

[12] Qureshi AS, Turral H, and Masih I, 2004. Strategies for the management of conjunctive use of surface waterand groundwater resources in semi-arid areas: A case study from Pakistan. Research Report 86. International Water Management Institute 